Canadian

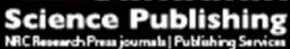

Environmental Reviews Dossiers environnement

\title{
Processes and pathways of ciguatoxin in aquatic foodwebs and fish poisoning of seafood consumers
}

\begin{tabular}{|r|l|}
\hline Journal: & Environmental Reviews \\
\hline Manuscript ID & er-2015-0054.R1 \\
\hline Manuscript Type: & Review \\
\hline Complete List of Authors: & $\begin{array}{l}\text { Yang, Zhiyi; Shenzhen Institutes of Advanced Technology, } \\
\text { Luo, Qian; Shenzhen Institutes of Advanced Technology, } \\
\text { Liang, Yan; Shenzhen Institutes of Advanced Technology, } \\
\text { Mazumder, Asit ; Shenzhen Institutes of Advanced Technology, ; University } \\
\text { of Victoria, }\end{array}$ \\
\hline Keyword: & $\begin{array}{l}\text { ciguatoxin, ciguatera food poisoning, marine foodweb, ecological } \\
\text { distribution, biotransfer }\end{array}$ \\
\hline &
\end{tabular}

\section{SCHOLARONE \\ Manuscripts}


1 Processes and pathways of ciguatoxin in aquatic foodwebs and fish poisoning of

2 seafood consumers

3 Zhiyi Yanga, Qian Luo*, Yan Liang, and Asit Mazumder ${ }^{1}$

4 Shenzhen Institutes of Advanced Technology, Chinese Academy of Sciences, 518055

5 Shenzhen, China

$6{ }^{1}$ Water and Aquatic Sciences Research Program, University of Victoria, Victoria, BC,

$7 \quad$ V8W 3N5, Canada

8

9 Corresponding author:

10 * Shenzhen Institutes of Advanced Technology, Chinese Academy of Sciences, Shenzhen

11 518055, China. Tel.: +86 755 86585330; fax: +86 755 86585247; E-mail: qian.luo@siat.ac.cn

12

13 Current affiliation:

14 a State Key Laboratory of Environmental and Biological Analysis, Hong Kong Baptist

15 University, Kowloon Tong, Hong Kong SAR, China

16

17 Word count: 3324 words 
1 Abstract: Ciguatera food poisoning (CFP) is widespread in tropical and sub-tropical

2 waters, and it is the most common food poisoning caused by marine biotoxins. The

3 toxins involved, ciguatoxins, are produced by certain dinoflagellates of the genus

4 Gambierdiscus, and undergo biotransfer and biomagnification up the foodweb to

5 planktivorous and ultimately, top predator fishes. In this paper, we reviewed the factors

6 and processes that regulate the production of ciguatoxins, the ecological distribution and

7 the pathways of their biotransfer, and fish consumption guidelines to prevent ciguatera

8 related food poisoning. Warm waters are commonly suggested as the most important

9 factor that enhances toxic algal blooms and ciguatoxin production. Ecological

10 distribution of ciguatoxic fish shows great regional specificity. In most endemic areas,

11 carnivores such as groupers and other large fish have higher toxicity than their

12 herbivorous and smaller counterparts, supporting the food chain hypothesis proposed by

13 Randall (1958); while in other areas, for example, French Polynesia, the opposite

14 situations also exist, questioning the biomagnification hypothesis. Some countries and

15 regions have taken measurements to prevent ciguatera poisoning through consumption

16 guidelines. In this review, we look at some of the measures that could be used to prevent

17 poisoning, while encouraging people to consume fish. For example, choosing smaller and

18 lower trophic level fish are likely to be safer to consume. We suggest an approach to

19 maintain better databases on ciguatera cases to instruct people on fish consumption

20 safety, and develop a general guideline for fish consumption to reduce CFP.

21 Key words: ciguatoxin, ciguatera food poisoning, marine foodweb, ecological

22 distribution, biotransfer, prevention 


\section{1. Introduction}

2 Ciguatera food poisoning (CFP) is a foodborne disease caused by consumption of fish

3 containing ciguatoxins (CTXs). It is the most common type of food poisoning by marine

4 biotoxins (EFSA Panel on Contaminants in the Food Chain 2010), although cases of CFP

5 are widely underreported (Dickey and Plakas 2010). According to different estimations,

6 about 10,000 to 500,000 people worldwide are infected by CFP each year (Chinain et al.

7 2010b; Gingold et al. 2014). Victims of CFP suffer from acute neurological,

8 gastrointestinal and cardiovascular symptoms, and in some cases also sexual dysfunction

9 (Dickey and Plakas 2010; Stewart et al. 2010).

The term, "ciguatera", was coined in the $18^{\text {th }}$ century by the European settlers on the

12 Caribbean islands to describe the neurological syndromes of food poisoning (Pearn 2001).

While there have been many advances on CFP research since the first successful isolation

of ciguatoxin from moray eel by Scheuer et al. (1967), there are major knowledge gaps in several areas. Firstly, the food chain hypothesis proposed by Randall (1958) illustrates that the ciguatera toxins are transferred from algae through planktivores and herbivores to carnivorous fish. This hypothesis has won much early approval and has been especially supported by the discovery of ciguatoxin in benthic dinoflagellate Gambierdiscus toxicus by Adachi and Fukuyo (1979). While the food-chain hypothesis has become a widely accepted theory on the mechanism of ciguatoxin transfer (Lewis and Holmes 1993 and references therein), there have been observations from coastal subtropical and tropical oceans that are not consistent with the food-chain hypothesis. 
Secondly, it is challenging to understand the factors and processes regulating temporal and spatial distribution of ciguatoxin-producing algae and the accumulation of the toxin in aquatic foodwebs leading to CFP through fish consumption. Based on Randall's theory, the assumption has been that ciguatoxicity in fish increases with size or age within a single species (Caillaud et al. 2010), or with trophic level across all the species in a CFP endemic area.

A third challenge regarding ciguatoxin in fish and other seafood is in the development of integrative consumption guidelines. CTX intoxication does not change the appearance or smell of the fish, thus making it difficult for consumers to judge whether a fish is toxic or not. As a rule of thumb, the size and trophic level assumptions are commonly suggested in the guidelines for seafood consumers. For example, the Centre for Food Safety of Hong Kong Government recommended the public to "consume less coral reef fish, especially marine fish over three catties $(1.8 \mathrm{~kg})$ ". The Centre has also showed that the fish species with a high potential of ciguatoxicity reported in Hong Kong are mainly groupers (Serranidae), which are top predators in coral reef ecosystems (Centre for Food Safety 2006). However, recent studies have shown some contradictory results for different species and CFP endemic areas (Gaboriau et al. 2014 and references therein; Darius et al. 2007). Hence, newer guidelines need to be established in order to incorporate the latest knowledge on CFP. 
In this review, we discuss the factors and processes determining toxin production by a select group of marine algae, the global distribution of ciguatoxins, the pathways of ciguatoxin in the aquatic foodweb, and management of health risks from CFP through consumption guidelines. We will also review recent studies that have confirmed or contradicted the well-recognized assumptions, and try to provide a feasible guideline to prevent CFP for fish consumers.

\section{Factors and processes regulating CTX production by algae}

CTXs are produced by the species of the benthic dinoflagellate Gambierdiscus, especially G. toxicus, the first discovered from the coral reefs at the Gambier Islands, French Polynesia (Yasumoto et al. 1977; Adachi and Fukuyo 1979). The genetic mechanisms regulating CTX production are not yet clear, but it is believed that the CTX biosynthesis is mediated by polyketide synthase (PKS), a pathway undergone by brevetoxins that is structurally similar to CTXs (Chinain et al. 2010a; Kalaitzis et al. 2010; for structures, see

Fig. 1). These toxins have been categorized as P-CTXs, C-CTXs, and I-CTXs, according to their locations of discovery in the Pacific, Caribbean, and Indian Ocean, respectively (Vernoux and Lewis 1997; Hamilton et al. 2002a, 2002b).

The toxin molecules are lipid-soluble polyethers with polycyclic backbones. As of now, more than 40 congeners of CTXs have been isolated. With the help of nuclear magnetic resonance (NMR) and mass spectrometry techniques, the structure of 14 congeners have been elucidated (Murata et al. 1990; Lewis et al. 1998; Yasumoto et al. 2000; Yasumoto 
2001; Pottier et al. 2002), and new congeners have been categorized by their probable structures (for example, with an open ring) (Chinain et al. 2010a). The most common CTX congeners, namely P-CTX-1, -2 and -3 are quantified by liquid chromatography-tandem mass spectrometry (LC-MS/MS) method, and their respective limits of quantification are 0.50, 5.00 and $5.00 \mathrm{pg} / \mathrm{g}$ wet weight (Mak et al. 2013), which are three orders of magnitudes below their respective $\mathrm{LD}_{50}$ levels (Lewis 2001).

In general, Gambierdiscus species are distributed in various coastal ecosystems of tropical and sub-tropical waters, with north and south latitudinal boundaries between $35^{\circ} \mathrm{N}$ and 37 S (Parsons et al. 2012; Hallegraeff 2010). Species of Gambierdiscus found in the Atlantic and Pacific oceans differ greatly, although the endemic areas share only a few of the same species (Litaker et al. 2010). This difference is also linked to the distinction in the structure of CTXs produced in each region. At a local scale, the distribution of Gambierdiscus is sporadic and region-specific, and can be linked to the occurrence of ciguatoxic fish in a small area (Dickey and Plakas 2010), while non-ciguateric site can be located just a few kilometers away from a ciguateric site (Chan et al. 2011; O'Toole et al. 2012).

Warm water has long been suspected as the most important factor leading to toxic algal blooms and CTX production, as suggested by the common occurrence of CFP incidences in warm water fish. Relationships between sea surface temperature (SST) and the incidence rates of CFP have been studied for Caribbean nations and territories (Tester et 

al. 2010). All the CFP incidences reported during 1996 to 2006 took place where average annual SST exceeded $25^{\circ} \mathrm{C}$. The regions that were most prone to CFP, namely Montserrat and Antigua-Barbuda, had the warmest water, with surface temperatures above $25^{\circ} \mathrm{C}$ during the coldest month of February. Six species of Gambierdiscus have optimum or positive growth rates between 25 and $29^{\circ} \mathrm{C}$ in culture (Litaker et al. 2010; Tester et al. 2010). Similarly, growth and ciguatoxicity of G. polynesiensis strains, isolated from French Polynesia and cultured at $27^{\circ} \mathrm{C}$, were also found to be positive as a function of temperature (Chinain et al. 2010a).

It is also suggested that the geographical distribution of Gambierdiscus might widen with anticipated future warming of coastal marine ecosystems (Tester et al. 2010). Ciguatera occurences in the Northeastern Atlantic region, an area that was long considered non-endemic to CFP, have raised public concern since the first CFP outbreak in the Canary Islands in 2004 (Pérez-Arellano et al. 2005), when C-CTX-1 was detected in amberjack fish (Seriola rivoliana). During the same time, Gambierdiscus sp. were found in Canarian water by another research group (Aligizaki et al. 2008), thus providing evidence supporting the expansion of Gambierdiscus. It is suspected the outbreak is related to an exceptional heat wave in 2003, as in the case of Ostreopsis bloom, another genus of dinoflagellate (Fraga et al. 2012). Subsequently, the number of CFP cases in the Canary Islands has exceeded 68 (Nuñez et al. 2012), and CTXs have also been detected from two starfish species in the Portuguese islands of Madeira and Azores (Silva et al. 2015). 
112 In addition, other environmental factors could also be linked to CTX production. Low

113 light intensities have also been suggested to stimulate Gambierdiscus proliferation (Fraga

114 et al. 2012). Many species of Gambierdiscus have maximum growth at a salinity of around

11530 , though some other species displayed different salinity preferences (Parsons et al.

116 2012). The influence of nutrients on the growth of Gambierdiscus remains unclear, as

117 benthic dinoflagellates can bloom in waters with low nutrient concentrations (Parsons et

118 al. 2012). However, it is still not clearly understood why some of these dinoflagellates

119 produce toxins in one location, but not in a nearby location.

\section{Global distribution of CTX in aquatic foodwebs}

122 Ciguatoxin is transferred along the aquatic foodwebs through consumption of prey, and

123 is found at different trophic levels from invertebrates to planktivorous, to herbivorous

124 fish to top predators (Darius et al. 2007; Mak et al. 2013). Lewis $(1993,2001)$ reported a

125 more complicated distribution of P-CTX congeners in dinoflagellates and fish. He

126 reported that P-CTX-1, a typical CTX congener found in carnivorous fish, is a more

127 oxidized form and is 10 times more toxic than P-CTX-4B found in algae (Fig. 1). It was

128 also reported that all the P-CTX congeners found in algae and herbivores (namely,

129 P-CTX-3C, 4A, and 4B) have lower potency than any congener that comes from

130 carnivorous fishes. It has been suggested that the biotransformation processes may occur

131 in fish, which may lead to biomagnification of CTX along aquatic foodwebs. 
As early as Randall (1958), large piscivorous fish have been frequently found to be the only group that caused ciguatera endemic toxicity. Besides the bioaccumulation and biomagnification processes, the biotransformation into more toxic forms in fish may provide an explanation supporting this observation. CTX prevalence in species of groupers (Serranidae), a family of carnivores in coral reef ecosystems, is profound in many countries and territories. CFP caused by these fish has been imposing great risk to public health because of their popularity as a seafood.

Meanwhile, the ecological distribution of CTX also shows regional specificity. In the Noumea Fish Market, New Caledonia, as many as 28 risky species of fish were reported by Clua et al. (2011). These fish were harvested from the Southern and Northern Provinces of New Caledonia. Groupers, mackerels and snappers were the fish groups with risky concentrations of CTX were most commonly found. Apart from the species observed in fish markets, giant moray (Gymnothorax javanicus), peacock grouper (Cephalopholis argus), and three snappers namely Lutjanus bohar, Lutjanus monostigma, and Lutjanus rivulatus were recognized as the most toxic species and were restricted from sale on the market.

In Okinawa, Japan, CFP outbreaks during 1997 to 2006 have been most frequently related to serranids such as Variola louti, L. bohar and L. monostigma. In a batch of serranids, the percentage of toxic individuals topped at 32.3\% for L. monostigma (Oshiro et al. 2010). In Hong Kong and other coastal cities in South China, CFP cases caused from consumption 
155

156

157

158

159

160

161

162

163

164

165

166

167

168

169

170

171

172

173

174

175

176

of coral reef fishes such as groupers, snappers and humphead wrasses (Cheilinus undulatus) are common (Wong et al. 2005). Among those fish involved in the CFP cases that occurred in Hong Kong, two-spot red snappers (L. bohar) and leopard coral groupers (Plectropomus leopardus) have been the most common species (Wong et al. 2014). Several clinical studies on these cases have been carried out by local hospitals (Chan 2013, 2014).

\section{New approaches to study the transfer and bioaccumulation of CTX in the foodweb}

\subsection{Ciguatoxin accumulation as a function of body size}

Although the Randall (1958) size assumption is widely accepted, studies in recent years often show contradictory results and highly species-specific and region-dependent variability. Researchers testing the size-assumption theory have observed a significant but weak positive correlation $\left(p=0.03, r^{2}=1.5 \%\right)$ between the CTX toxicity and the length of peacock groupers (C. argus) from Hawaii (Dierking and Campora 2009), and a strong and significant correlation for moray eels (Gymnothorax spp.) from the coastal waters of Kiribati (Chan et al. 2011; Mak et al. 2013).

However, there are results showing no significant correlation between the CTX toxicity and the fish weight or length for the horse-eye jacks (Caranx latus) caught from St. Barthelemy (Pottier et al. 2002), for nine species of fish from Tubuai, for twenty-one species from Nuku Hiva, French Polynesia (FP) (Darius et al. 2007), for peacock groupers (C. argus) from Hawaii (Bienfang et al. 2012), and for great barracudas (Sphyraena barracuda) from the Bahamas (O'Toole et al. 2012). These results have also been supported 
177 by observations by Caillaud et al. (2012) on lesser amberjacks (Seriola fasciata) from the 178 Canary Islands.

Chinain et al. (2010b) found that within herbivorous species from Raivavae Island, French

Polynesia (FP), smaller individuals had greater concentrations of CTX than the bigger

individuals of the same species. In a more recent article, the same research group showed negative correlations between CTX concentration in fish tissue and fish total length for seven species $\times$ island ( 2 carnivores, 1 omnivore and 4 herbivores) in FP (Gaboriau et al.

2014). It is worthy to note, that much like their previous study, here too they found that

smaller herbivorous fish had higher concentrations than the larger ones. Interestingly,

while the carnivorous Epinephelus polyphekadion in Fakarava produced a negative relationship between toxicity and total length, another carnivorous fish species, L. bohar observations led us speculate that aside from size, it would be important to take note of size at a given age of a fish because faster growing fish may show lower toxin concentrations, which is often considered a growth dilution process (e.g., the case for brevetoxins reported in Perrault et al. 2014).

\subsection{Transfer of ciguatoxin along aquatic foodwebs}

Long-term records collected over at least ten years may be required to robustly understand the factors and processes regulating CTX transfer along aquatic foodwebs.

198 Chateau-Degat et al. (2005) reported a correlation between high Gambierdiscus spp. cell 
199

200

201

202

203

204

205

206

207

208

209

density in the Atiamaono coral reef, Tahiti, and high sea-water temperature with a 17-month lag time. They also reported a correlation between CFP breakouts in local communities and a high density of dinoflagellates 3 months before. In another study, increases in CFP cases in the United States were proven to be associated with a high SST 18 months prior in the Caribbean basin (Gingold et al. 2014). Both reports, although focusing on different oceans, were consistent in reporting a substantial time lag between peak SST and peak CTX concentrations in top predators.

Compared to the timescale of CTX transfer in the foodweb, the depuration process is relatively slow. Based on a study of moray eels in the central Pacific (Lewis et al. 1992), the half-life of the depuration process, including possible biotransformation processes that reduce toxicity, have been estimated to be 264 days. Rapid declines in CFP cases (e.g., 90 to 300 days for a 50\% decline) found elsewhere in the Pacific may be regarded as a result of a similar half-life (Lewis and Holmes 1993; Lehane and Lewis 2000).

Mak et al. (2013) introduced the stable nitrogen isotope analysis method into ecological studies of ciguatoxin. A systematic increase in ${ }^{15} \mathrm{~N}$ from prey to predator has been used as a quantitative measure of trophic dynamics in a foodweb (Cabana and Rasmussen 1994; Vander Zanden and Rasmussen 2001) and associated bioaccumulation process also aquatic foodwebs. For fish and invertebrate samples from Marakei, Kiribati, significant positive relationships have been observed between ${ }^{15} \mathrm{~N}$ and $\log$ P-CTX-1 concentrations. However, these relationships did not show for P-CTX-2/-3, which may suggest that 
biomagnification of ciguatoxins could be a result of biotransformation from P-CTX-2/-3 to P-CTX-1 (Fig. 2, adapted from Mak et al. 2013). In contrast to the findings outlined above, Darius et al. (2007) reported that herbivores in Nuku Hiva, FP had greater ciguatoxicity than species at higher trophic levels, which is surprising given that herbivorous fishes are first in the transfer pathway chain of ciguatoxin.

\section{Prevention and management of health risk}

In many regions where coral reef fish are largely sold and consumed, local measurements are taken to fight against CFP. Due to the high regional specificity of CFP distribution, for example, herbivorous fishes are most highly ciguatoxic in French Polynesia, counter-measurements vary from one to another endemic area.

\section{Island residents of French Polynesia use a series of home tests to examine whether a fish} is toxic, for example, to feed it to a dog or a cat (Chinain 2010b). Also, traditional remedies are commonly used within local communities when CFP symptoms appeared. However, with fish as their staple source of protein, the island residents often resume eating fish once the symptoms disappear (Dickey and Plakas 2010).

Cigua-Check ${ }$ is a commercially available test kit for detecting ciguatoxins produced by ToxiTec Inc., Hawaii, based on an enzyme immunoassay originally developed by Hokama (1985). Although the reliability of the kit is disputed because of some false positives and false negatives from known samples of fish with CTX (Wong et al. 2005; 
243 Campora et al. 2006), it is accepted by institutes and public health authorities in the

244 Philippines and Thailand to examine the ciguatoxicity of fish flesh samples (Mendoza et 245 al. 2013; Sintunawa et al. 2014).

Consumption guidelines on fish in markets and restaurants are mainly based on size or weight of fish. Lehane and Lewis (2000) reported that some Australian restaurants would not accept coral trouts above $2.5 \mathrm{~kg}$. In New Caledonia, the fish species that are considered as the most toxic are not allowed for sale in the market. In Hawaii, the great amberjacks (Seriola dumerilii) above $20 \mathrm{lbs}(9 \mathrm{~kg})$ are prohibited to be sold in the market (Clua et al. 2011). In Hong Kong, coral reef fish weighing above $1.8 \mathrm{~kg}$ are advised not to be consumed (Centre for Food Safety 2006).

Databases of CFP reports can provide useful instructions for health risk prevention. On the internet database "FishBase" (www.fishbase.org, Froese and Pauly 2015), an alarming total of 207 entries of fish species are listed under the topic "ciguatera". In French and the Institut Louis Malardé (ILM) since the mid-1960s. Hospitals, health centers and volunteer public health physicians send records containing age, symptoms and other

261 information of the patient for each case to the authorities. Trends of local CFP risks can be analyzed using this database. However, it is believed that only $20 \%$ of the total CFP cases 
case reports to the authorities (Chateau-Degat et al. 2007; Chinain et al. 2010b).

\section{Conclusion}

Among the many factors and processes that trigger CTX production by the select group of dinoflagellates, sea surface temperature seems to be the most important driving force. However, more extensive research is needed before all the factors can be fully understood. Although trophic transfer and bioaccumulation with increasing trophic level and body size have been commonly considered as the major factors determining CTX toxicity in fish, other toxicity transformation along aquatic foodwebs should also be considered in alternative models. Considering the complexity of processes regulating CTX production and biotransfer, a more comprehensive plan for preventing CFP should be used to account for variability in scenarios in various coastal regions in the tropical and sub-tropical areas. Such a plan would require a high level of international cooperation on seafood safety. First of all, institutions managing international databases on CFP reports should cooperate with clinics and hospitals from more countries and regions, and encourage them to report more recent CFP cases. Second, due to the time lag between CFP blooms and high SST of local sea water, it is of much significance to monitor SST in current and potential CFP endemic areas, which would allow better prediction of potential high toxicity of fish and health risk from CFP. Third, seafood markets should require retailers to mark the time and location of harvested fish, which will allow consumers knowledge-based decision making on potential CFP risks. Last but not least, current regulations based on fish size or weight should continue to be used 
287 because consumers can easily understand the regulations and associated risks.

288 Meanwhile, we will be working on improving the guidelines that incorporate

289 bioaccumulation and biotransformation processes for commonly consumed fish species.

290 


\section{Acknowledgements}

292 This study was supported by grants awarded from CAS Adjunct Professorship (No.

293 2013T1G0038), China Bureau of Foreign Experts Affairs ([2014] No. 49), Guangdong

294 Science and Technology Department (No. 20130320c), and Shenzhen Science, Technology

295 and Innovation Commission (No. JCYJ20140417113430578). The authors would also like

296 to show acknowledgement to the editors and reviewers of this article for their detailed

297 revision and comments. 


\section{References.}

2

3

4

5

6

Adachi, R., and Fukuyo Y. 1979. The Thecal Structure of a Marine Toxic Dinoflagellate Gambierdiscus toxicus gen. et sp. nov. Collected in a Ciguatera-endemic Area. Bull. Jpn. Soc. Sci. Fish. 45(1):67-71.

Aligizaki, K., Nikolaidis, G., and Fraga, S. 2008. Is Gambierdiscus expanding to new areas? Harmful Algae News (36):6-7.

Bienfang, P., DeFelice, S., Laws, E., Wallsgrove, N., and Caldwell, P. 2012. Ciguatoxicity in the main Hawaiian Islands: spatial and temporal variability in the introduced reef carnivore Cephalopholis Argus. J. Res. Environ. Sci. Tox. 1(3):47-57.

Cabana, G., and Rasmussen, J. 1994. Modelling food chain structure and contaminant bioaccumulation using stable nitrogen isotopes. Nature 372:255-257.

Caillaud, A., de la Iglesia, P., Darius, H.T., Pauillac, S., Aligizaki, K., Fraga, S., Chinain, M., and Diogène, J. 2010. Update on Methodologies Available for Ciguatoxin Determination: Perspectives to Confront the Onset of Ciguatera Fish Poisoning in Europe. Mar. Drugs 8:1838-1907.

Caillaud, A., Eixarch, H., de la Iglesia, P., Rodriguez, M., Dominguez, L., Andree, K.B., and Diogène, J. 2012. Towards the standardisation of the neuroblastoma (neuro-2a) cell-based assay for ciguatoxin-like toxicity detection in fish: application to fish caught in the Canary Islands. Food Addit. Contam. Part A 29(6):1000-1010.

Campora, C.E., Hokama, Y., and Ebesu, J.S.M. 2006. Comparative Analysis of Purified Pacific and Caribbean Ciguatoxin Congeners and Related Marine Toxins Using a 
Modified ELISA Technique. J. Clin. Lab. Anal. 20:121-125.

Centre for Food Safety, The Government of the Hong Kong Special Administrative Region 2006. Ciguatera Fish Poisoning [online]. Available from http://www.cfs.gov.hk/english/whatsnew/whatsnew fsf/whatsnew fsf poison fish. html [accessed 8 December 2015].

Chan, T.Y.K. 2013. Ciguatera caused by consumption of humphead wrasse. Toxicon 76:255-259.

Chan, T.Y.K. 2014. Large Outbreaks of Ciguatera after Consumption of Brown Marbled Grouper. Toxins 6(7):2041-2049.

Chan, W.H., Mak, Y.L., Wu, J.J., Jin, L., Sit, W.H., Lam, J.C.W., Sadovy de Mitcheson, Y., Chan, L.L., Lam, P.K.S., and Murphy, M.B. 2011. Spatial distribution of ciguateric fish in the Republic of Kiribati. Chemosphere 84:117-123.

Chateau-Degat, M.-L., Chinain, M., Cerf, N., Gingras, S., Hubert, B., and Dewailly, E. 2005. Seawater temperature, Gambierdiscus spp. Variability and incidence of ciguatera poisoning in French Polynesia. Harmful Algae 4:1053-1062.

Chateau-Degat, M.-L., Dewailly, E., Cerf, N., Nguyen, N.L., Huin-Blondey, M.-O., Hubert, B., Laudon, F., and Chansin, R. 2007. Temporal trends and epidemiological aspects of ciguatera in French Polynesia: a 10-year analysis. Trop. Med. Int. Health 12(4):485-492.

Chinain, M., Darius, H.T., Ung, A., Cruchet, P., Wang, Z., Ponton, D., Laurent, D., and Pauillac, S. 2010a. Growth and toxin production in the ciguatera-causing dinoflagellate Gambierdiscus polynesiensis (Dinophyceae) in culture. Toxicon 
56:739-750.

Chinain, M., Darius, H.T., Ung, A., Tchou Fouc, M., Revel, T., Cruchet, P., Pauillac, S., and Laurent, D. 2010b. Ciguatera risk management in French Polynesia: The case study of Raivavae Island (Australes Archipelago). Toxicon 56:674-690.

Clua, E., Brena, P.F., Lecasble, C., Ghnassia, R., and Chauvet, C. 2011. Prevalence and proposal for cost-effective management of the ciguatera risk in the Noumea fish market, New Caledonia (South Pacific). Toxicon 58:591-601.

Darius, H.T., Ponton, P., Revel, T., Cruchet, P., Ung, A., Tchou Fouc, M., and Chinain, M. 2007. Ciguatera risk assessment in two toxic sites of French Polynesia using the receptor-binding assay. Toxicon 50:612-626.

Dickey, R.W., and Plakas, S.M. 2010. Ciguatera: A public health perspective. Toxicon $56: 123-136$.

Dierking, J., and Campora, C.E. 2009. Ciguatera in the Introduced Fish Cephalopholis argus (Serranidae) in Hawai'i and Implications for Fishery Management. Pacific Science 63(2):193-204.

EFSA Panel on Contaminants in the Food Chain 2010. Scientific Opinion on marine biotoxins in shellfish - Emerging toxins: Ciguatoxin group. EFSA Journal 8(6):1627. [38 pp.]. doi:10.2903/j.efsa.2010.1627.

Fraga, S., Rodríguez, F., Bravo, I., Zapata, M., and Marañón, E. 2012. Review of the main ecological features affecting benthic dinoflagellate blooms. Cryptogamie, Algologie 33(2):171-179.

Froese, R., and Pauly, D. (Editors). 2015. FishBase. World Wide Web electronic publication, 
version (10/2015) [online]. Available from http://www.fishbase.org [accessed 9 December 2015].

Gaboriau, M., Ponton, D., Darius, H.T., and Chinain, M. 2014. Ciguatera fish toxicity in French Polynesia: Size does not always matter. Toxicon 84:41-50.

Gingold, D.B., Strickland, M., and Hess, J.J. 2014. Ciguatera Fish Poisoning and Climate Change: Analysis of National Poison Center Data in the United States, 2001-2011. Environ. Health Perspect. 122(6):580-586.

Hallegraeff, G.M. 2010. Ocean climate change, phytoplankton community responses, and harmful algal blooms: A formidable predictive challenge. J. Phycol. 46:220-235.

Hamilton, B., Hurbungs, M., Vernoux, J.-P., Jones, A., and Lewis, R.J. 2002a. Isolation and characterisation of Indian Ocean ciguatoxin. Toxicon 40:685-693.

Hamilton, B., Hurbungs, M., Vernoux, J.-P., Jones, A., and Lewis, R.J. 2002b. Multiple ciguatoxins present in Indian Ocean reef fish. Toxicon 40:1347-1353.

Hokama, Y. 1985. A rapid, simplified enzyme immunoassay stick test for the detection of ciguatoxin and related polyethers from fish tissues. Toxicon 23(6):939-946.

Kalaitzis, J.A., Chau, R., Kohli, G.S., Murray, S.A., and Neilan, B.A. 2010. Biosynthesis of toxic naturally-occurring seafood contaminants. Toxicon 56:244-258.

Lehane, L., and Lewis, R.J. 2000. Ciguatera: recent advances but the risk remains. Int. J. Food. Microbiol. 61:91-125.

Lewis, R.J. 2001. The changing face of ciguatera. Toxicon 39:97-106.

Lewis, R.J., and Holmes, M.J. 1993. Origin and transfer of toxins involved in ciguatera. Comp. Biochem. Physiol. 106C(3):615-628. 
Lewis, R.J., Sellin, M., Street, R., Holmes, M.J., and Gillespie, N.C. 1992. Excretion of Ciguatoxin from Moray Eels (Muraenidae) of the Central Pacific. In Proceedings of the Third International Conference on Ciguatera Fish Poisoning, La Parguera, Puerto Rico, 30 April - 5 May 1990. Edited by T.R. Tosteson. Polyscience Publications, Morin Heights, Quebec. pp. 131-143.

Lewis, R.J., Vernoux, J.-P., and Brereton, I.M. 1998. Structure of Caribbean ciguatoxin isolated from Caranx latus. J. Am. Chem. Soc. 120(24):5914-5920.

Litaker, R.W., Vandersea, M.W., Faust. M.A., Kibler, S.R., Nau, A.W., Holland, W.C., Chinain, M., Holmes, M.J., and Tester, P.A. 2010. Global distribution of ciguatera causing dinoflagellates in the genus Gambierdiscus. Toxicon 56:711-730.

Mak Y.L., Wai, T.-C., Murphy, M.B., Chan, W.H., Wu, J.J., Lam, J.C.W., Chan, L.L., and Lam, P.K.S. 2013. Pacific Ciguatoxins in Food Web Components of Coral Reef Systems in the Republic of Kiribati. Environ. Sci. Technol. 47:14070-14079.

Mendoza, C.O., Rabanes, A.C., Jimenez, E.C., Azanza, R.V., Cortez-Akhunzadah, J., and Cruz, L.J. 2013. Detection of ciguatera fish poisoning in the Philippines. J. Environ. Sci. Manag. (Special Issue 1-2013):50-55.

Murata, M., Legrand, A.M., Ishibashi, Y., Fukui, M., and Yasumoto, T. 1990. Structures and Configurations of Ciguatoxin from the Moray Eel Gymnothorax javanicus and Its Likely Precursor from the Dinoflagellate Gambierdiscus toxicus. J. Am. Chem. Soc. 112:4380-4386.

Nuñez, D., Matute, P., Garcia, A., Garcia, P., and Abadía, N. 2012. Outbreak of ciguatera food poisoning by consumption of amberjack (Seriola spp.) in the Canary Islands, 

May 2012. Euro Surveill. 17(23):pii=20188. Available from:

\section{http://www.eurosurveillance.org/ViewArticle.aspx?ArticleId=20188 [accessed 9} December 2015].

Oshiro, N., Yogi, K., Asato, S., Sasaki, T., Tamanaha, K., Hirama, M., Yasumoto, T., and Inafuku, Y. 2010. Ciguatera incidence and fish toxicity in Okinawa, Japan. Toxicon $56: 656-661$.

O’Toole, A.C., Dechraoui Bottein, M.-Y., Danylchuk, A.J., Ramsdell, J.S., and Cooke, S.J. 2012. Linking ciguatera poisoning to spatial ecology of fish: A novel approach to examining the distribution of biotoxin levels in the great barracuda by combining non-lethal blood sampling and biotelemetry. Sci. Total Environ. 427-428:98-105.

Parsons, M.L., Aligizaki, K., Dechraoui Bottein, M.-Y., Fraga, S., Morton, S.L., Penna, A., and Rhodes, L. 2012. Gambierdiscus and Ostreopsis: Reassessment of the state of knowledge of their taxonomy, geography, ecophysiology, and toxicology. Harmful Algae 14:107-129.

Pearn, J. 2001. Neurology of ciguatera. J. Neurol. Neurosurg. Psychiatry 70:4-8.

Pérez-Arellano, J.-L., Luzardo, O.P., Pérez Brito, A., Hernández Cabrera, M., Zumbado, M., Carranza, C., Angel-Moreno, A., Dickey, R.W., and Boada, L.D. 2005. Ciguatera Fish Poisoning, Canary Islands. Emerging Infectious Diseases 11(12):1981-1982.

Perrault, J.R., Schmid, J.R., Walsh, C.J., Yordy, J.E., and Tucker, A.D. 2014. Brevetoxin exposure, superoxide dismutase activity and plasma protein electrophoretic profiles in wild-caught Kemp's ridley sea turtles (Lepidochelys kempii) in southwest Florida. Harmful Algae 37:194-202. 
133

134

Pottier I., Vernoux, J.-P., Jones, A., and Lewis, R.J. 2002. Characterization of multiple Caribbean ciguatoxins and congeners in individual specimens of horse-eye jack (Caranx latus) by high-performance liquid chromatography / mass spectrometry. Toxicon 40:929-939.

Randall, J.E. 1958. A Review of Ciguatera, Tropical Fish Poisoning, with a Tentative Explanation of its Cause. Bull. Mar. Sci. 8(3):236-267.

Scheuer, P.J., Takahashi, W., Tsutsumi, J., and Yoshida, T. 1967. Ciguatoxin: Isolation and Chemical Nature. Science 155:1267-1268.

Silva, M., Rodriguez, I., Barreiro, A., Kaufmann, M., Neto, A.I., Hassouani, M., Sabour, B., Alfonso, A., Botana, L.M., and Vasconcelos, V. 2015. First Report of Ciguatoxins in Two Starfish Species: Ophidiaster ophidianus and Marthasterias glacialis. Toxins $7: 3740-3757$

Sintunawa, C., Wacharapluesadee, S., Sarava, A., and Hemachudha, T. 2014. Surveillance of marine fish for ciguatera toxin at fish markets in Bangkok, Thailand. Asian Biomed. 8(2):263-268.

Stewart, I., Lewis, R.J., Eaglesham, G.K., Graham, G.C., Poole, S., and Craig, S.B. 2010. Emerging tropical diseases in Australia. Part 2. Ciguatera fish poisoning. Ann. Trop. Med. Parasitol. 104(7):557-571.

Tester, P.A., Feldman, R.L., Nau, A.W., Kibler, S.R., and Litaker, R.W. 2010. Ciguatera fish poisoning and sea surface temperatures in the Caribbean Sea and the West Indies. Toxicon 56:698-710.

Vander Zanden, M.J., and Rasmussen, J.B. 2001. Variation in $\delta^{15} \mathrm{~N}$ and $\delta^{13} \mathrm{C}$ trophic 
155

156

157

158

159

160

161

162

163

164

165

166

167

168

169

170

fractionation: Implications for aquatic food web studies. Limnol. Oceanogr. 46(8):2061-2066.

Vernoux, J.-P., and Lewis, R.J. 1997. Isolation and characterisation of Caribbean ciguatoxins from the horse-eye jack (caranx latus). Toxicon 35(6):889-900.

Wong, C.-K., Hung, P., Lee, K.L.H., and Kam, K.-M. 2005. Study of an outbreak of ciguatera fish poisoning in Hong Kong. Toxicon 46(5):563-571.

Wong, C.-K., Hung, P., and Lo, J.Y.C. 2014. Ciguatera fish poisoning in Hong Kong - A 10-year perspective on the class of ciguatoxins. Toxicon 86:96-106.

Yasumoto, T. 2001. The Chemistry and Biological Function of Natural Marine Toxins. Chem. Rec. 1:228-242.

Yasumoto, T., Nakajima, I., Bagnis, R., and Adachi, R. 1977. Finding of a Dinoflagellate as a Likely Culprit of Ciguatera. Bull. Jpn. Soc. Sci. Fish. 43(8):1021-1026.

Yasumoto, T., Igarashi, T., Legrand, A.-M., Cruchet, P., Chinain, M., Fujita, T., and Naoki, H. 2000. Structural Elucidation of Ciguatoxin Congeners by Fast-Atom Bombardment Tandem Mass Spectroscopy. J. Am. Chem. Soc. 122:4988-4989. 
1 Table 1. Confirmed significant correlations between toxicity and fish size in literatures. (Abbreviations: FP = French Polynesia)

\begin{tabular}{|c|c|c|c|c|c|c|c|c|}
\hline Family & Species & Trophic category & Location & p-value & Positive/negative & $\mathrm{R}^{2}$ & Number of samples & Reference \\
\hline Serranidae & $\begin{array}{l}\text { Cephalopholis } \\
\text { argus }\end{array}$ & Carnivorous & $\begin{array}{l}\text { Oahu \& Hawaii, } \\
\text { Hawaii }\end{array}$ & 0.03 & positive & 0.015 & 291 & Dierking and Campora 2009 \\
\hline Muraenidae & $\begin{array}{l}\text { Gymnothorax } \\
\text { flavimarginatus }\end{array}$ & Carnivorous & $\begin{array}{l}\text { Marakei, } \\
\text { Kiribati }\end{array}$ & $<0.05$ & positive & 0.267 & 15 & Mak et al. 2013 \\
\hline Muraenidae & $\begin{array}{l}\text { Gymnothorax } \\
\text { javanicus }\end{array}$ & Carnivorous & $\begin{array}{l}\text { Marakei, } \\
\text { Kiribati }\end{array}$ & $<0.01$ & positive & 0.425 & 18 & Mak et al. 2013 \\
\hline Lutjanidae & Lutjanus bohar & Carnivorous & Fakarava, FP & 0.008 & positive & 0.854 & 6 & Gaboriau et al. 2014 \\
\hline Serranidae & $\begin{array}{l}\text { Epinephelus } \\
\text { polyphekadion }\end{array}$ & Carnivorous & Fakarava, FP & $<0.001$ & negative & 0.431 & 24 & Gaboriau et al. 2014 \\
\hline Carangidae & $\begin{array}{l}\text { Pseudocarenx } \\
\text { dentex }\end{array}$ & Carnivorous & Rapa, FP & 0.035 & negative & 0.296 & 15 & Gaboriau et al. 2014 \\
\hline
\end{tabular}




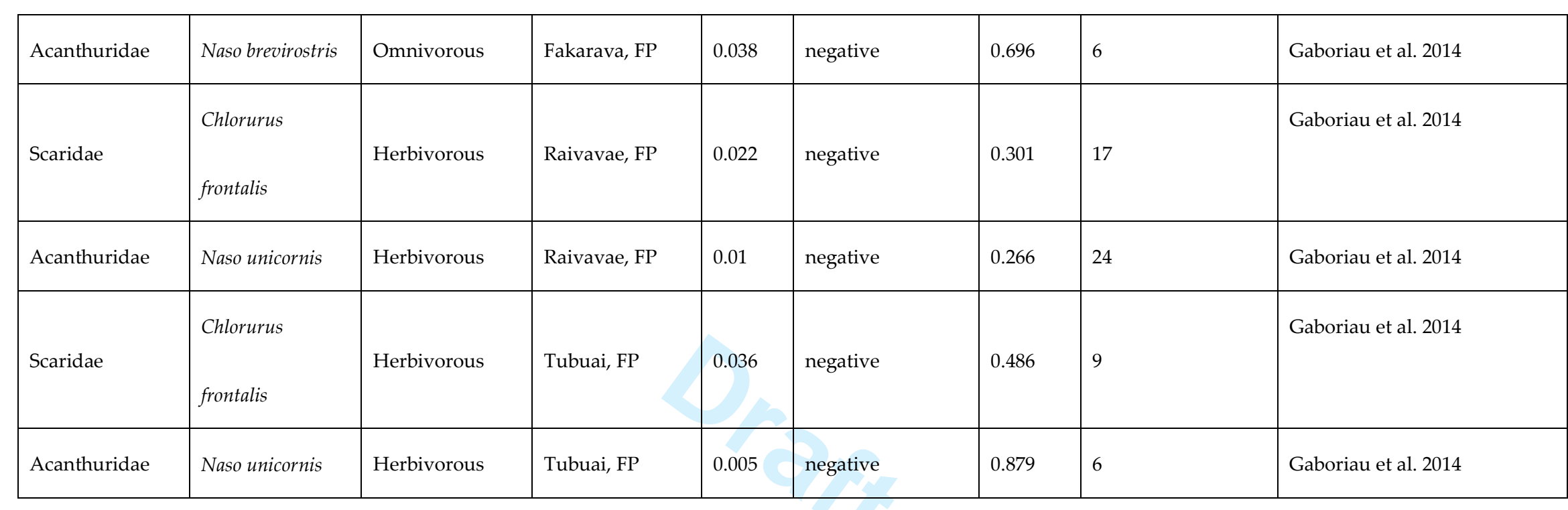




\section{$1 \quad$ Figure Legends}

2 Fig. 1. Structures of common ciguatoxins and brevetoxin.

3 Fig. 2. Pathways of P-CTXs in the foodweb system in Marakei, Kiribati (Adapted with

4 permission from Mak et al. 2013. Copyright 2013 American Chemical Society).

5

6 


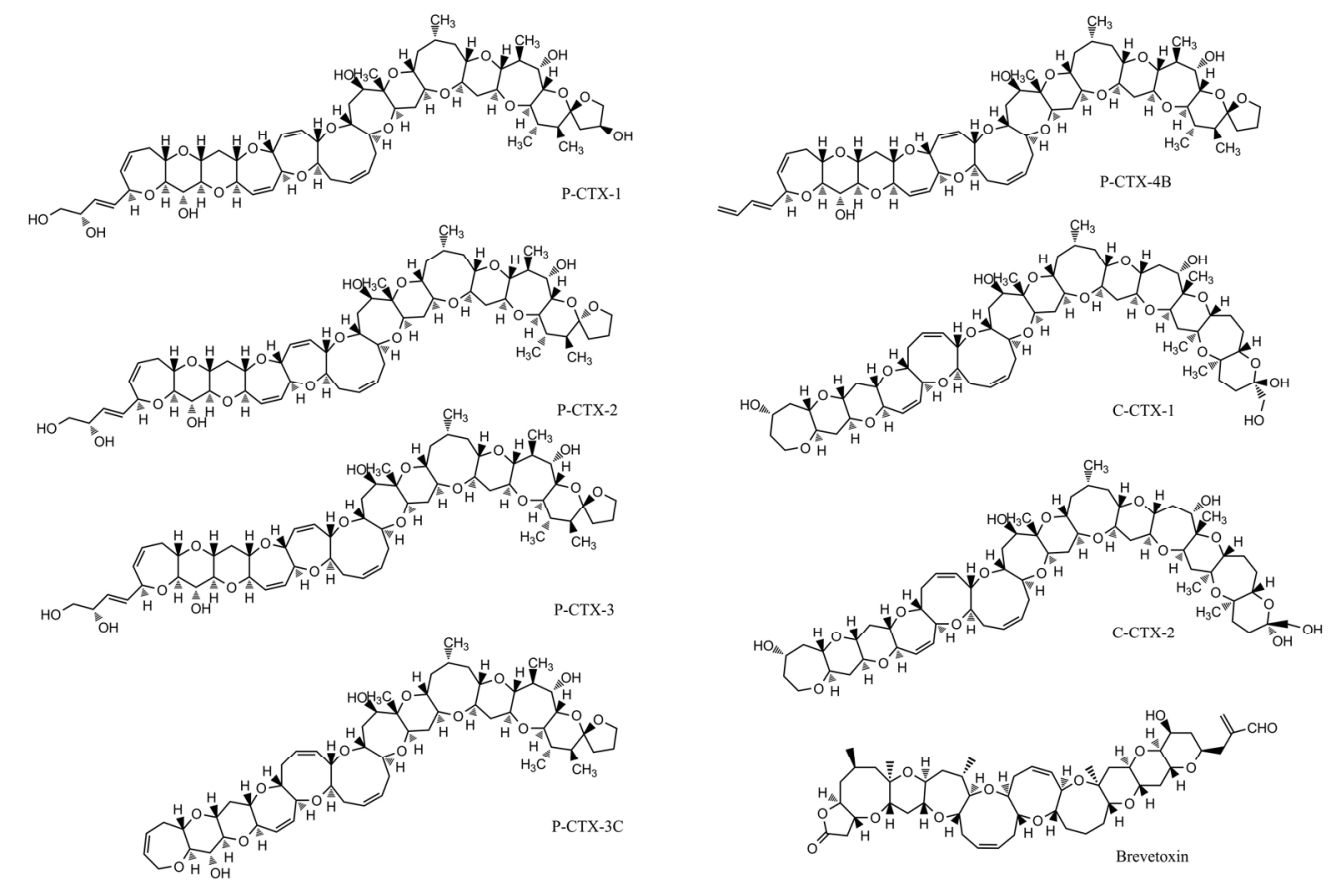

Fig. 1. Structures of common ciguatoxins and brevetoxin. $523 \times 350 \mathrm{~mm}(96 \times 96 \mathrm{DPI})$ 


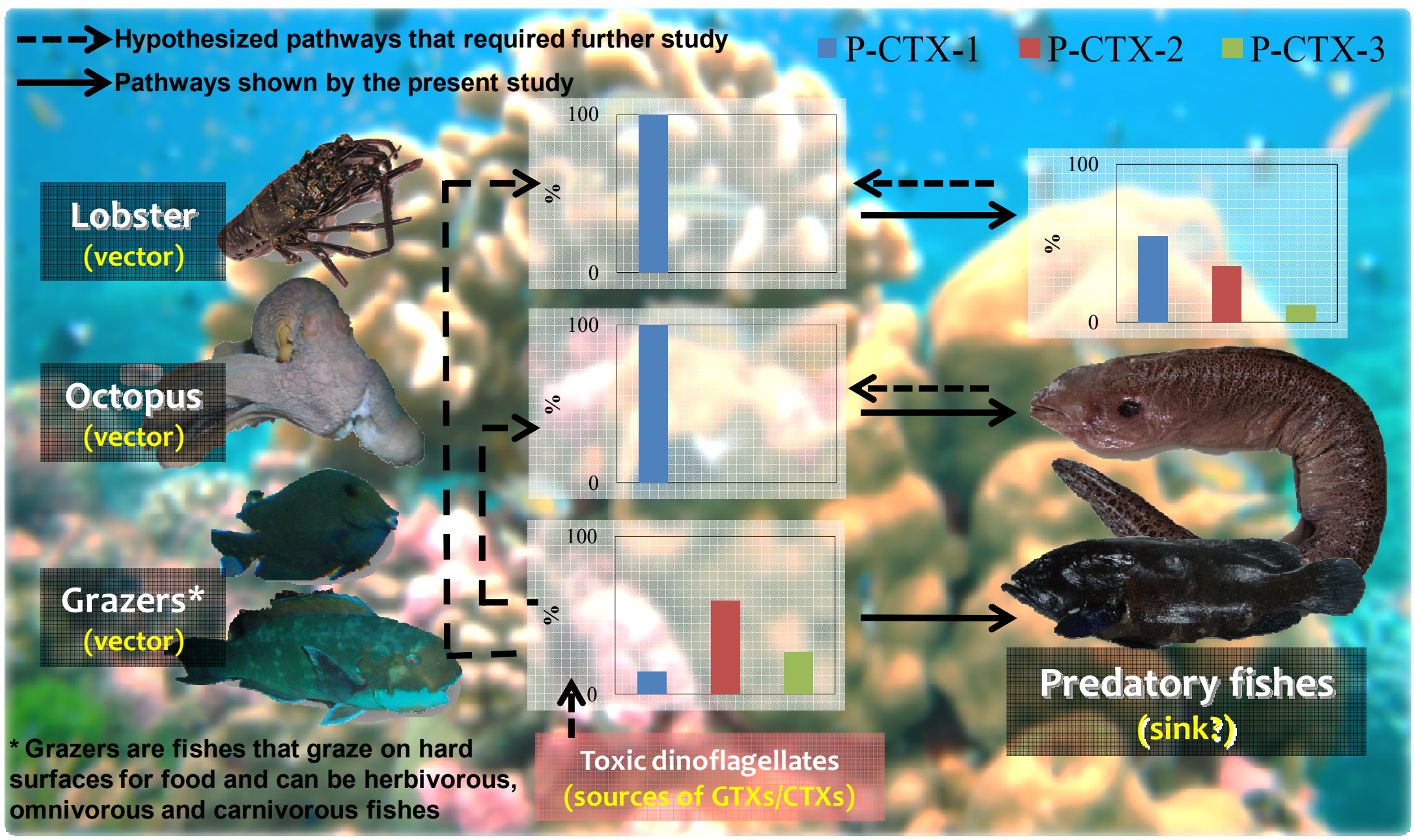

